\title{
AS PINTURAS RUPESTRES DA TRADIÇÃO NORDESTE NA REGIÃO DO SERIDÓ, RN, NO CONTEXTO DA ARTE RUPESTRE BRASILEIRA
}

\section{THE RUPESTRAL PAINTINGS OF THE NORTHEAST TRADITION IN THE SERIDÓ REGION, RN, IN THE CONTEXT OF BRAZILIAN RUPESTRY ART}

\author{
Anne-Marie Pessis ${ }^{1}$ \\ annepessis@gmail.com
}

Gabriela Martin ${ }^{1}$

gabrielamartinavila@gmail.com

\begin{abstract}
Resumo
Este artigo é uma reflexão sobre as pinturas rupestres da tradição Nordeste na região arqueológica do Seridó, que precisam ainda de estudos pormenorizados do seu vasto acervo arqueológico. Se pode afirmar que, paralelamente às pinturas do Parque Nacional Serra da Capivara, no estado do Piauí, os conjuntos rupestres do Seridó representam o maior acervo gráfico do nordeste do Brasil. Esta afirmativa não está apenas baseada na quantia dos sítios e dos registros, mas na riqueza imagética que os mesmos representam. Retratam as numerosas atividades da vida cotidiana e cerimonial dos povos que as fizeram, além da manifestação da cultural material, imaterial e técnica do pensamento abstrato indígena na pré-história brasileira.
\end{abstract}

Palavras chaves: Arte rupestre, Seridó, Tradição Nordeste

\footnotetext{
${ }^{1}$ Fundação Museu do Homem Americano, Fumdham e Docente, Programa de Pós-graduação em Arqueologia, UFPE.
} 


\begin{abstract}
This article is a reflection on the cave paintings of the Northeast tradition in the archaeological region of Seridó, which still need detailed studies of their vast archaeological collection. It can be said that, in parallel to the paintings in the Serra da Capivara National Park in the state of Piauí, the rock paintings ensembles of Seridó represent the largest graphic heritage in the northeast of Brazil. This statement is not just based on the number of sites and records, but on the wealth of images that they represent. They portray the numerous activities of the daily and ceremonial life of the peoples who did them, as well as the manifestation of the material, immaterial and technical culture of indigenous abstract thought in Brazilian prehistory.
\end{abstract}

Keyword: Rock Art, Seridó, Northeast tradition.

A primeira publicação no Brasil resultado de uma pesquisa arqueológica referente às pinturas rupestres descobertas no Parque Nacional Serra da Capivara, no Piauí, aparece em 1980 e 1981 (Guidon; Andreatta,1980, Guidon,1981) seguida das primeiras notícias relativas às pinturas do Seridó (Martin,1981,1982). Inicia-se assim a longa trajetória que confirmaria a existência de um horizonte cultural que chamaremos Tradição Nordeste segundo nomenclatura designada para determinados conjuntos de registros rupestres pré-históricos pintados. Já na década de1980 foram estabelecidos duas macros categorias básicas na sistematização inicial para o estudo da arte rupestre no Nordeste do Brasil. Foram categorias de entrada que definiam preliminarmente duas classes de pintura pré-histórica, denominadas Nordeste e Agreste.

Com anterioridade, na década de 1970, quando se iniciaram as pesquisas no SE do

Piauí por parte da missão arqueológica franco-brasileira, houve publicações na 
França e apresentação de resultados preliminares em congressos internacionais e nas reuniões de Arqueologia em Goiás que foram predecessoras da fundação da Sociedade de Arqueologia Brasileira - SAB em 1980. (Guidon, 1973,1975, 1976; Pessis, 1982; Martin, 1975,1977).

Nas mais de quatro décadas que separam aquelas primeiras publicações das atuais determinaram-se as caraterísticas gerais dessa tradição pictórica que, em linhas gerais, apresenta figuras de pequeno tamanho (raramente ultrapassam $10 \mathrm{~cm}$ de altura), com cenas apresentando ações através de posturas e gestos humanos e de grupos de animais. A diversidade das figuras, as características técnicas, a maneira como as pinturas se distribuem sobre o suporte, a existência de cenas emblemáticas ${ }^{2}$ e o reconhecimento dos temas escolhidos permitiram identificar o padrão gráfico de um tronco cultural, conhecido como tradição Nordeste. A partir dessa classe de pinturas rupestres inicia-se um processo de registro gráfico no nordeste do Brasil, que atravessa o tempo e o espaço.

Esses aspectos gerais foram a base descritiva de um extenso horizonte cultural. Descrições mais ou menos acertadas se aplicam às numerosas variáveis que os espaços e os tempos parecem indicar. Subtradições, estilos, variedades, complexos

${ }^{2}$ Se conhecem como desenho emblemáticos de uma tradição rupestre, cenas ou grafismos que se repetem na maioria dos abrigos e cujo significado desconhecemos. Esse fato está amplamente constatado nas pinturas rupestres da tradição Nordeste. 
e classes sucedem-se, em subdivisões que se fazem necessárias com o avanço das pesquisas na ampla geografia nordestina.

A criação dos cursos de pós-graduação em Arqueologia nas IES federais a partir da década de 1990 estimula entre docente e alunos a procura de novos sítios. A Arte Rupestre está de moda; funda-se a ABAR Associação Brasileira de Arte Rupestre durante uma reunião do IFRAO ${ }^{3}$ em Portugal e que consegue seu ponto mais alto no posterior IFRAO reunido em 2009 na sede da Fundação Museu do Homem Americano em São Raimundo Nonato, no Piauí, (Anais do Congresso Internacional de Arte Rupestre - IFRAO, FUMDHAMentos IX, 2010).

Porém, porque sempre há um, "porém", junto a trabalhos sérios que são maioria, aparecem e se publicam absurdidades com pretensões estilísticas classificatórias, cronologias imaginárias e, por provincialismos, se pretende demostrar as origens das representações rupestres em regiões determinadas como se de o onphalos das origens se tratara. Ao difusionismo que caracterizou boa parte da pré-história global no século XX, se impõem nacionalismos de valorização do "nosso" e as ideologias pessoais transcendem também na interpretação da pré-história.

${ }^{3}$ International Federation of Rock Art Organizations (IFRAO). 
A pesar do aumento da produção bibliográfica em relação ao tema, o problema continua sendo, principalmente, a dificuldade de relacionar com dados científicos seguros o registro rupestre dos sítios com as ocupações humanas dos mesmos, salvo raras e felizes ocasiões em que a estratigrafia arqueológica nos tem fornecido datações relativas ante quem para os registros gráficos. Assim, podemos afirmar que, até o presente, não existem datações absolutas para as pinturas rupestres préhistóricas da região Nordeste do Brasil, na sua extensão de mais de um milhão de quilômetros quadrados, embora, a riqueza antropológica registrada nos painéis rupestres nos compensem da falta desses dados absolutos. Identificamos grupos humanos organizados em bandos originários de um mesmo tronco cultural, um padrão técnico pouco complexo e uma relação de equilíbrio com a natureza. A indústria lítica evidencia uma função utilitária simples e é possível pensar que as prioridades dessas comunidades estivessem orientadas por questões em que os dispositivos técnicos não eram prioritários. A ausência de desenvolvimento tecnológico coincide com o aparecimento da prática gráfica rupestre, realizada sobre as paredes dos abrigos sob rocha. A narratividade das pinturas, representando cenas da vida cotidiana e cerimonial, são indicadores essenciais para se entender quais eram os temas prioritários entre os grupos humanos que estavam já instalados na região sudeste do Piauí.

As pinturas rupestres existentes nos abrigos são diversificadas, tanto na temática como na técnica de realização. Existem pinturas que são reconhecidas de imediato, enquanto que outras evocam formas incompletas ou não reconhecíveis. Cada 
conjunto é resultante de uma sucessão de desenhos realizados em épocas diferentes por diversos grupos étnicos e configura uma amostragem da pintura pré-histórica da região. Nesse conjunto de imagens dispostas ao acaso, se misturam ritos, mitos, símbolos, acontecimentos sociais e crenças, confundidos no tempo. Está caracterizada pela presença de figuras que permitem o reconhecimento e pela maneira como essas figuras se relacionam para representar acontecimentos.

Realizadas com aprimoramento técnico, que reflete um domínio dos recursos gráficos, as pinturas fornecem ao observador, os elementos essenciais para reconhecer o que representam. Através de posturas e gestos, mostram figuras representando ações. O que as diferencia são as escolhas temáticas e as modalidades de encenação utilizadas em cada situação. Durante os milênios em que foram realizadas as pinturas da Tradição Nordeste, aparecem temas que se repetem regularmente, embora as repetições apresentem diferenças de encenação. Os temas representam rituais, lúdicos ou cerimoniais, caçadas e cenas sexuais.

\section{Da Serra da Capivara ao Seridó: os caminhos possíveis}

As vias pelas quais foi povoada a região nordeste do Brasil ficam ainda imprecisas. Sabemos que comunidades humanas habitavam o que hoje é o Parque Nacional Serra da Capivara, situado na região SE do estado do Piauí desde o fim do Pleistoceno Superior. As condições climáticas tropical-úmidas, que precederam ao clima semiárido atual, permitiram o desenvolvimento de uma vegetação abundante, que garantiu os recursos alimentares para uma fauna de grande porte e majoritariamente herbívora. Há cerca de 9 mil anos, começou o processo de 
mudança climática que vai radicalizar as condições de existência na região. Ocorre uma diminuição das chuvas, iniciando-se uma gradativa transformação do clima tropical-úmido. Esse processo, iniciado por causas naturais a nível planetário, significou mudanças no regime de ventos e correntes marítimas que aconteceram na transição do Pleistoceno ao Holoceno.

A vegetação foi a primeira a adequar-se às novas condições climáticas. A flora úmida foi gradativamente substituída pelas espécies que melhor se adaptaram às novas condições. Existem, ainda hoje, vestígios dessa primeira vegetação tropicalúmida, nas profundezas dos canyons que, durante as épocas de seca, mantém as condições de umidade necessárias para sua sobrevivência, perto de pontos de água perene, conhecidos como olhos d'água. São gotas de água que brotam das paredes das encostas, do fundo da pedra, e caem em ritmo regular, em todas as estações do ano. Essa água se acumula em depressões formadas pela erosão na rocha e em torno dos pontos de umidade, desses nichos ecológicos, conservam-se algumas espécies da flora que milênios atrás cobriam a região.

O processo de adaptação da vegetação às novas condições do clima deu lugar a um tipo de flora própria dessas condições climáticas: a caatinga. Em resposta a essa transformação do ambiente que afetou diferenciadamente a região nordeste, existiu a reação das comunidades humanas. Existem evidências que condicionam fortemente a organização dos grupos humanos, com o crescimento demográfico detectado pelas pesquisas arqueológicas. Esse aumento da população caracteriza 
um período de transição traumático, em que são estabelecidas novas condições de vida que determinaram novas regras de comportamento. Mas um aumento da população exige também uma mudança das formas de organização social até então existentes. As comunidades humanas estavam organizadas em pequenos grupos, o que facilitava sua mobilidade e seus tempos de reação, frente a qualquer possibilidade de perigo que exigisse ações rápidas.

Testemunhos documentais a partir do século XVI mencionam como característica dos grupos indígenas a capacidade de estar hoje num ponto e amanhã ter desaparecido sem deixar vestígios. Essa mobilidade era possível pelo número reduzido de indivíduos integrantes de cada grupo. As comunidades reagiram com vistas a manter o equilíbrio entre os diferentes grupos do mesmo tronco cultural. Assim, os grupos maiores começaram a se dividir em conjuntos menores, que, no decorrer das sucessivas gerações, foram adquirindo suas próprias identidades diferenciadoras, sem por isso renunciar à marca originária dada pelos ancestrais comuns.

Esse processo de fragmentação e diferenciação gera desequilíbrios de poder e hierarquia, na medida em que existe sempre uma ordem de precedência que pesa sobre os novos grupos. A procura de outros espaços territoriais constitui para as espécies vivas, um procedimento que permite o restabelecimento do equilíbrio inicial, com a afirmação das identidades grupais. 


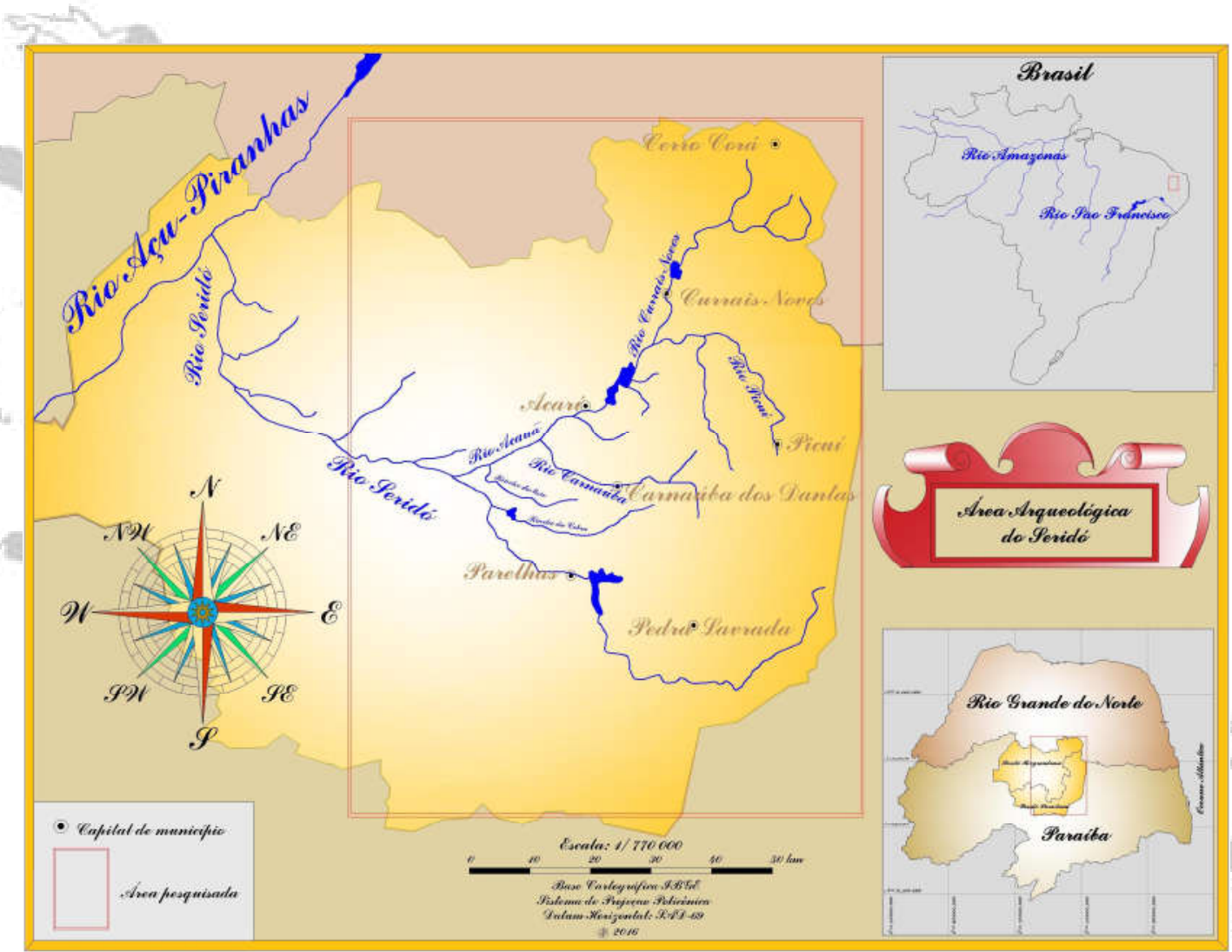

Figura 1. Mapa da área arqueológica do Seridó

A dispersão das comunidades da tradição Nordeste acontece nesse contexto de transformações e adaptações. Um movimento migratório inicia-se há 9 mil anos em direção à planície da bacia do Rio São Francisco. Os diferentes grupos avançam na procura de novos espaços que se adaptem melhor às suas expectativas, ficando em outros lugares e dispersando-se de forma gradativa ao tempo em que vão tornando mais precisa sua coesão grupal. Observações realizadas nas diferentes regiões que 
contornam o Parque Nacional Serra da Capivara permitiram constatar a existência de pinturas rupestres, muitas vezes isoladas, em paredes de afloramentos rochosos ou abrigos sob rocha similares aos existentes na região de origem.

Levaram também seu acervo cultural, acumulado durante milênios e registrado através de modalidades gráficas, que respondiam a necessidades específicas. As pinturas rupestres constituíam uma série de marcadores destinados a memorizar, para as futuras gerações, a lembrança de tópicos, considerados prioritários pelas comunidades que se sucederam no tempo num mesmo espaço. A recorrência temática, cuja encenação varia no tempo, indica a permanência de interesses sobre os mesmos assuntos entre diversos grupos, embora apareçam certos elementos de apresentação que mudam no tempo e que se desenvolvem nos respectivos espaços de influência de cada comunidade.

Pelos dados disponíveis podemos estabelecer que, em torno do nono milênio BP, grupos originários da área do atual Parque Nacional Serra da Capivara dispersaramse por outras regiões do Nordeste brasileiro, abandonando seu primitivo habitat. Da região serrana limitada pelas grandes depressões periféricas do Parnaíba e do São Francisco, rumaram para outras áreas do Nordeste através do vale sanfranciscano. Nessas datas, grandes áreas do vale do São Francisco estavam já ocupadas por grupos humanos que habitavam os abrigos rochosos e os terraços do rio, em acampamentos temporários. Tecnologicamente, eram portadores de uma indústria lítica refinada, elaborada a partir de núcleos de sílex, calcedônia e quartzo, 
denominada Tradição Itaparica. Basicamente, o horizonte lítico da tradição Itaparica estende-se por áreas de cerrado, rico em fauna diversificada e de caatinga no Nordeste com fauna menos densa, razão pela qual os grupos nordestinos procuraram com maior intensidade os vales dos rios. Os restos alimentares coletados nos abrigos rochosos os apresentam como caçadores-pescadorescoletores generalizados, consumidores de microfauna, gastrópodes e peixes. Não podemos assegurar que os pintores dos abrigos rupestres da tradição Nordeste possam estar, de alguma maneira, relacionados com os grupos caçadores portadores da tecnologia lítica Itaparica, embora implementos líticos dessa tradição se encontrem nos abrigos pintados do Parque Nacional Serra da Capivara, no SE do Piauí.

Utilizamos o termo subtradição para definir um grupo desvinculado de uma tradição e adaptado a um meio geográfico e ecológico diferente, o que implicaria na soma de elementos gráficos novos. Assim, as subtradições da tradição Nordeste espalham-se por amplas áreas do nordeste brasileiro, algumas melhor definidas, outras precariamente detectadas. Encontramos grupos de abrigos sob rocha com pinturas rupestres da tradição Nordeste, nas suas diversas subtrações, no Parque Nacional Serra da Capivara no SE do Piauí, na região do vale do Seridó potiguar e paraibano e na Chapada Diamantina e área de Central, na Bahia, que formam as três grandes "províncias" rupestres da tradição Nordeste. 
Embora em outras regiões do nordeste brasileiro tenham sido registradas formas modificadas dessa Tradição, em sítios isolados possíveis áreas de passagem, tais como no vale do Catimbau, em Buíque pertencente à bacia do Ipanema, tributário do São Francisco e Afogados de Ingazeira em Pernambuco; na bacia do CurimatauCunhau, entre os estados do Rio Grande do Norte e da Paraíba; no vale alto da bacia do Piranha-Açu, onde na região de Vierópolis, $\mathrm{PB}$, um abrigo com pinturas da Tradição Nordeste apresentou uma ocupação humana datada em torno de 7000 anos BP. Também não podemos deixar de registrar as variáveis da tradição Nordeste assinaladas no Parque Nacional Cavernas do Peruaçu, em Minas Gerais.

Na medida em que o conhecimento sobre as pinturas rupestres no nordeste do Brasil se foi ampliando, se confirmou a existência de características comuns entre os grafismos documentados nas diferentes províncias rupestres da região. Esse fato indicava a existência de processos de difusão das ideias acompanhando a dispersão dos grupos humanos. As primeiras hipóteses sobre a origem das tradições de pintura rupestre nessa região assinalaram o epicentro da tradição Nordeste localizado na região do entorno da Serra da Capivara. Essa dispersão não se manifesta de forma lineal, mas em ondas com vias de ida e volta ainda caracterizadas atemporalmente pela falta de dados cronológicos suficientes. Essa hipótese pretende conduzir as futuras pesquisas para o estabelecimento de correlações entre as representações rupestres identificadas. 
Na procura das possíveis rotas da dispersão da tradição Nordeste para ouras regiões realizaram-se prospecções arqueológicas de sítios com pinturas rupestres na Chapada do Araripe como parte do projeto A dispersão da tradição Nordeste: da Serra da Capivara ao vale do Seridó (Pessis et ali, 2005). Pelas suas condições morfológicas e climáticas a Chapada do Araripe apresenta uma vegetação diversificada com áreas de floresta, cerrado e caatinga. Ocupa áreas de Pernambuco, Piauí e Ceará e pela sua importância biológica e abundância de fósseis foi indicada como Área de Proteção Ambiental da biodiversidade do cerrado e da caatinga. Foram assinalados um número considerável de sítios abertos com pinturas rupestres, embora muito deterioradas e sem elementos gráficos que indicaram uma rota de passo da tradição Nordeste.

\section{As pinturas rupestres da tradição Nordeste no Seridó}

Uma das levas da diáspora se instala na região de Seridó, onde pesquisas arqueológicas indicam ocupações humanas há 9 mil anos. Nessa região de serras da bacia do Rio Seridó, existem abrigos sob rocha com pinturas rupestres que apresentam características similares às da tradição Nordeste, registradas na Serra da Capivara. Na época em que se teria iniciado o processo de emigração das comunidades humanas, a escolha da região do Seridó se justificaria pela existência de numerosos pontos d'água e ao fato de constituir uma área de brejos, que tem características climáticas mais favoráveis e melhores condições de sobrevivência. As características morfológicas da área escolhida permitiram dar-se continuidade a seus modos de registro gráfico, reproduzindo os temas principais da sua cultura. 
Mas, junto com a instalação e adaptação a novas condições de vida, começa uma fase de diferenciação gráfica que atinge tanto as temáticas, quanto as técnicas de realização utilizadas e as modalidades de apresentação.

Tomando os grupos da tradição Nordeste na região do Seridó, pela localização dos abrigos com pinturas, verificamos que eles se encontram limitados numa área determinada entre os rios Seridó e seu tributário, o Carnaúba, além de outros córregos pertencentes também à bacia do Seridó. Ao redor, encontramos sítios com outras tradições e numerosos sítios com gravuras, mas as pinturas rupestres que temos identificado como da Subtradição Seridó dentro do macro divisão Nordeste, está claramente delimitada no ponto de interseção dos dois vales citados: o Seridó e o Carnaúba.

Essa área se localiza nos municípios de Carnaúba dos Dantas e Parelhas no Rio Grande do Norte e Picuí e Pedra Lavrada na Paraíba. Tanto assim, que consideramos essa área como a fronteira estilística dessa subtradição além de uma possível fronteira política de um grupo étnico determinado. Contrasta com essa delimitação da subtradição Seridó a extensão que atingem as gravuras rupestres na região, principalmente situadas sobre afloramentos rochosos ao longo de rios e córregos da região no vale do rio Seridó, com ocorrências no Seridó Oriental e Ocidental, além do Açu-Piranhas a cuja bacia o rio Seridó pertence. 
Existem certos sítios onde aparecem destacadas as características gráficas do que pode se designar como o "período Arcaico" da subtradição Seridó e que dá continuidade aos estereótipos gráficos de origem, caracterizando a época de instalação no novo habitat. O estabelecimento de uma renovada identidade gráfica se manifesta nas dimensões mencionadas.

No plano técnico, existe o aprimoramento de procedimentos no preparo das tintas, em que a consistência utilizada se adéqua ao grau de porosidade do suporte rochoso. Essa articulação originariamente observada na Serra da Capivara se generaliza na área do Seridó. Existe também a transformação nos traços de delineação das figuras que se tornam mais grossos que os das figuras do período Arcaico. Igualmente observa-se uma tendência a desenhar figuras de tamanho um pouco maior do que nas primeiras épocas. Finalmente pode mencionar-se a dominância de tonalidades mais acentuadas e contrastadas que particularizam as pinturas do que pode ser designado como um segundo período, o Recente da subtradição Seridó e que corresponde a uma instância de fixação da tradição Nordeste na região.

Em publicações anteriores tentamos estabelecer diferencias estilísticas entre períodos das pinturas do Seridó, embora não cronológicas em virtude da falta de dados. Renunciamos à determinação de estilos por que o elemento estilístico nos parece subjetivo e ligado à história da arte, definição da que procuramos nos afastar, mesmo reconhecendo que o termo Arte Rupestre seja utilizado universalmente. 
Assim, dois períodos: Arcaico e Recente, nos libram de regionalismos e derivados que cronologicamente não podemos demonstrar.

Um dos principais traços de identidade da subtradição Seridó no período Recente é a forma de desenhar as figuras humanas representando a cavidade bucal. São apenas as figuras dispostas de perfil, que salientam esta característica da face, embora no resto guardem seus aspectos originários. A representação da cabeça de perfil num traço simples marcadamente expressionista que lembra a forma da castanha do caju (Anacardum occidentale) conhecida como "cabeça de caju" Essa forma de representar a cabeça não é única da região do Seridó, já foi registrada em sítios da África e da Ásia e conhecemos ao menos um caso na Serra da Capivara, e na Lapa do Ballet, em Matozinhos, MG, mas em lugar algum é representada tão repetidamente e com tanta variedade de atributos com nas figuras humanas da subtradição Seridó.

Observamos que, em geral, o ângulo de abertura bucal é reduzido à mínima expressão necessária para que seja reconhecida sua função. Mas, em certos casos, o ângulo de abertura bucal é utilizado não apenas como identificador, mas também para exprimir emoções ou até sons. Um exemplo é uma cena de violência sexual no Sítio Xique-Xique II, (Figura 2), na que resulta evidente que uma figura central cativa foi desenhada com a cabeça orientada na vertical e com um ângulo de abertura bucal de uns 150 graus, o que evoca gritos e resistência, tema que se repete na Furna do Messias. Aliás, a riqueza dos grafismos indicando 
variáveis temporais, faz dos conjuntos gráficos do sítio do Messias um dos mais ricos e densos do Seridó, onde é possível observar-se diferentes fases estilísticas e de aproveitamento dos espaços.
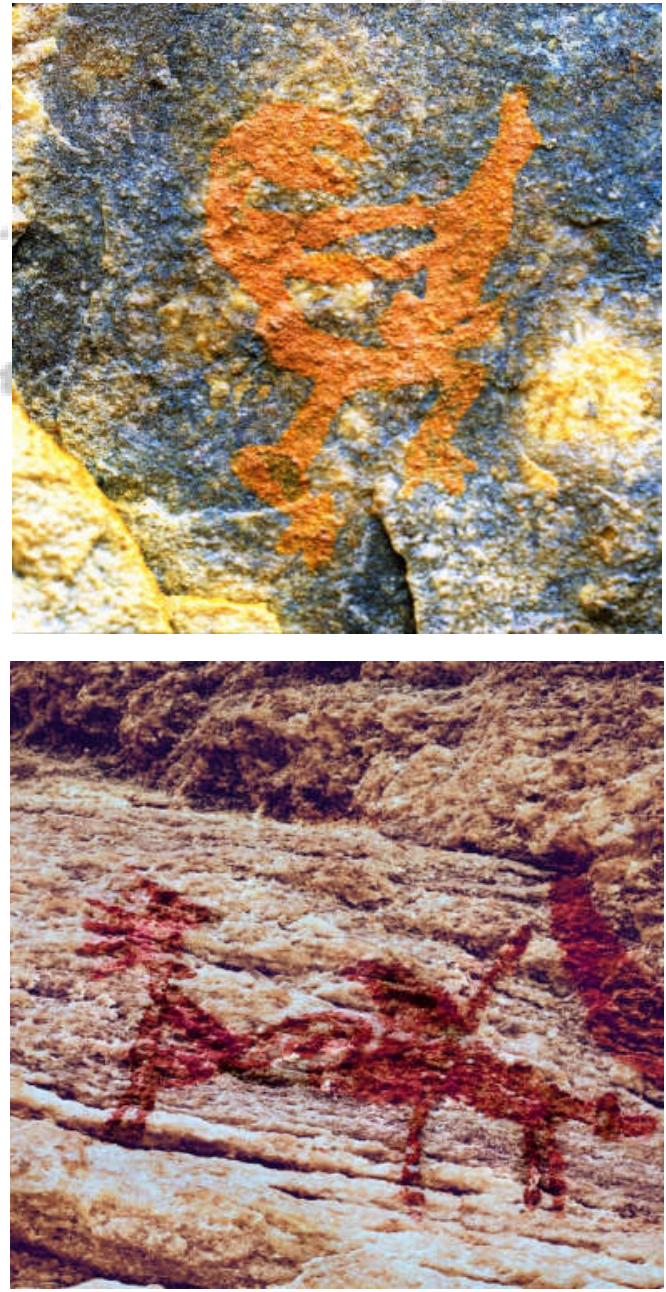

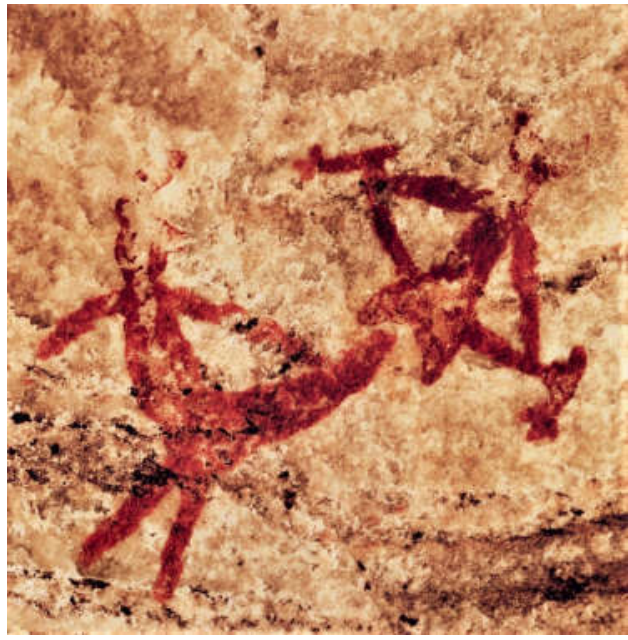

34

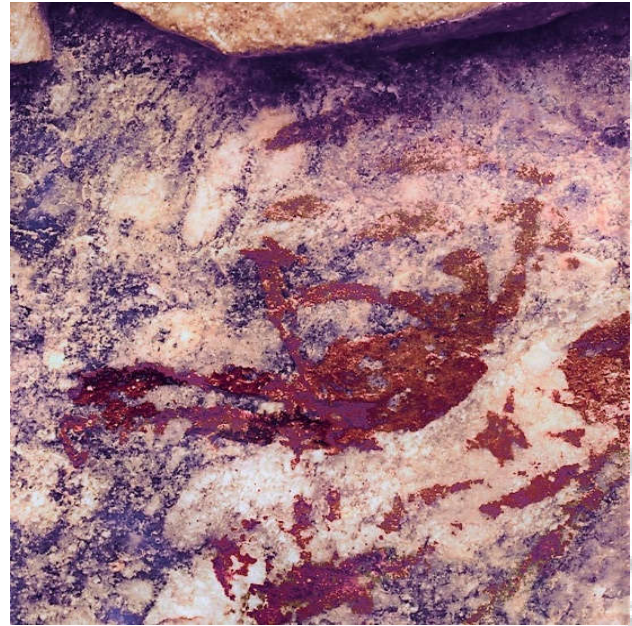

Figura 2. Cenas de violência sexual: A) Sítio Mirador; B) Sítio Xique-Xique II; C) Furna do Messias; E) Cena itifálica no Sítio Mirador. 
Continuando na caracterização da identidade Seridó, merece salientar-se a importância dada à representação de cocares e ornamentos na cabeça e no corpo assim como pintura corporal. Existe um grafísmo dominante na subtradição Seridó que está presente em praticamente todos os abrigos às vezes repetidamente, embora o desenho seja sempre diferente. Na Furna do Messias, por exemplo, aparece representado onze vezes, seja isolado ou relacionado com figuras humanas.

No Sítio do Alexandre, num lugar alto de difícil aceso, um desenho semelhante aparece com sete figuras humanas no interior formando parte do conjunto. Já fora considerado como a representação de pirogas, redes ou luas, entre outras explicações. Se bem sua representação está especialmente presente nos abrigos da subtradição Serido não é exclusivo dela, pois a encontramos, também, em pinturas da tradição Nordeste, na Pedra da Concha, Buique, PE; Sítio do Letreiro, Queimadas, PB e em Minas Gerais, (citado por Prous, 1983), como grafismos de tipo "nordestino". Consideramos esses grafismos como emblemáticos do período Recente da subtradição Seridó, (Figura 3). 

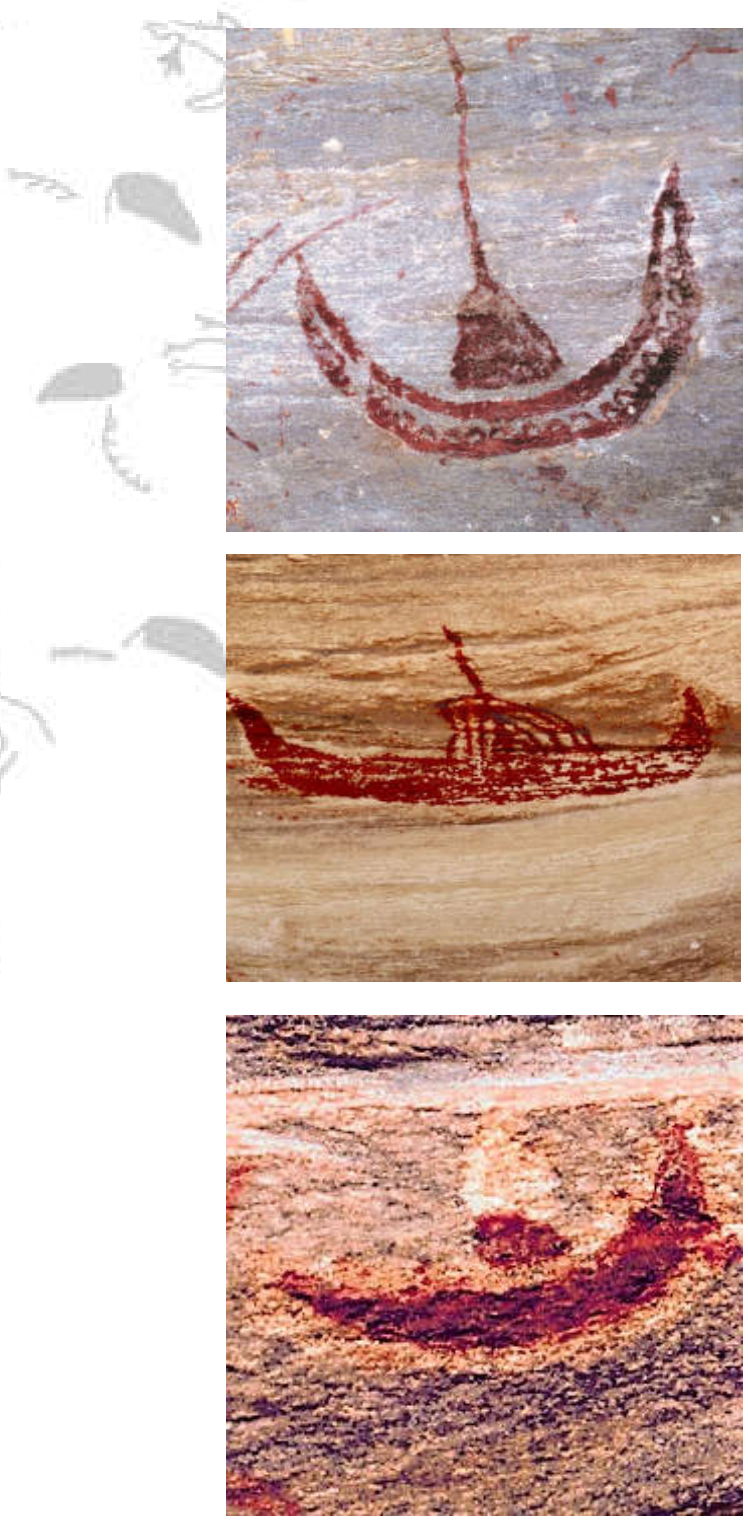
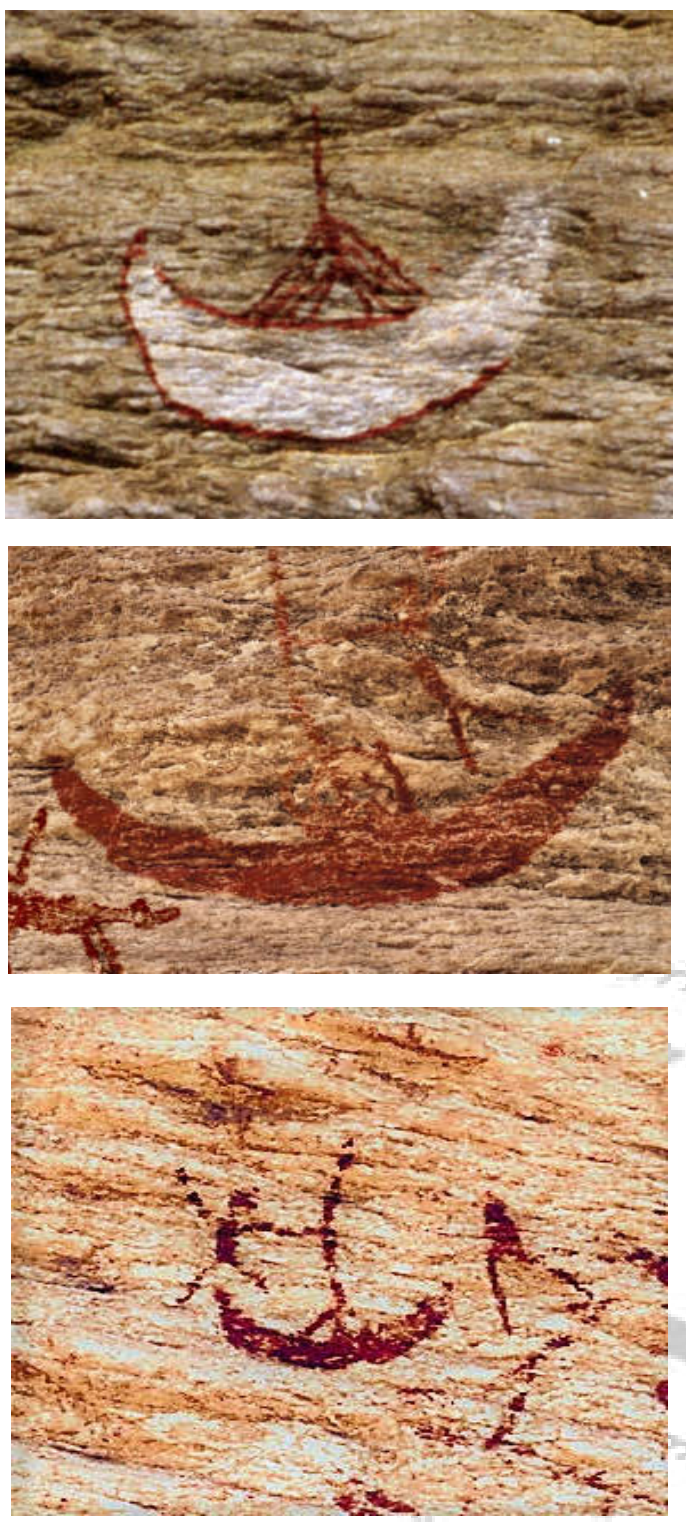

Figura 3. Grafismos emblemáticos de significado duvidoso e que se repetem em todos os sítios rupestres da subtradição Seridó: A) Sítio Casa Santa; B); C); D); E); F) Furna do Messias. 
O hermetismo é uma das características, nas pinturas rupestres, dos grupos de ação que consideramos emblemáticos, nos quais reconhecemos as figuras, mas a mensagem nelas contidas está perdida. Esse hermetismo poderia ser necessário para a manutenção das hierarquias no interior do grupo, das ideologias e da preservação das identidades. São figuras portadoras de múltiplos significados, porque os mesmos desenhos no interior de uma mesma cultura, experimentam variações de significação, segundo a história particular de cada grupo e da maneira como foram resolvidos os problemas que tiveram que encarar para sobreviver.

Por isso as figuras isoladas, humanas ou animais, não podem considerar-se "uma marca" de determinada variedade de pinturas ou, em todo caso, resultam menos confiáveis que a cena emblemática, na qual a ação se percebe embora não a entendamos. Um exemplo significativo de cena emblemática está formado por duas figuras humanas com uma menor no médio que parecem proteger ou apresentar, mas cujo significado apenas nos é sugerido, (Figuras 4a e 4b). Nos abrigos do Seridó essa cena repete-se praticamente em todos os sítios, embora com variadas formas de apresentação, desde figuras simples sem atributos até outras com dimorfismo sexual acentuado e riqueza de adornos e objetos.

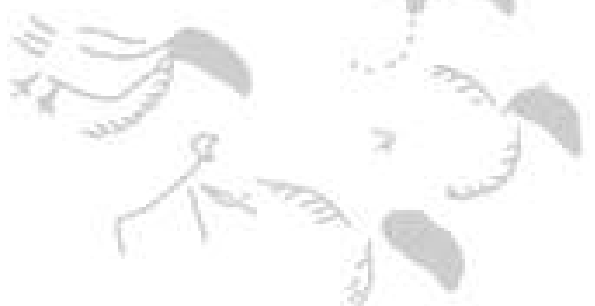



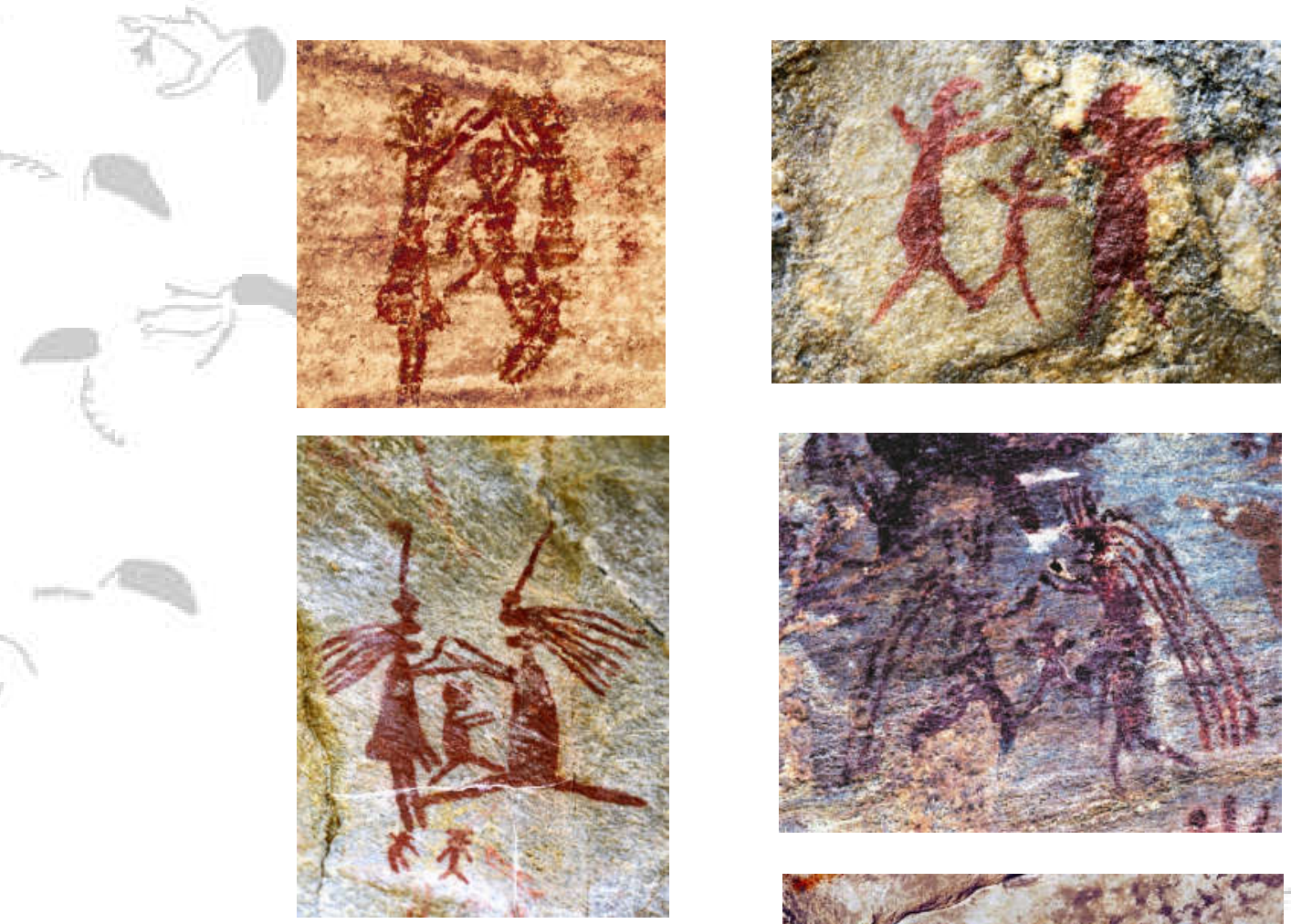

38
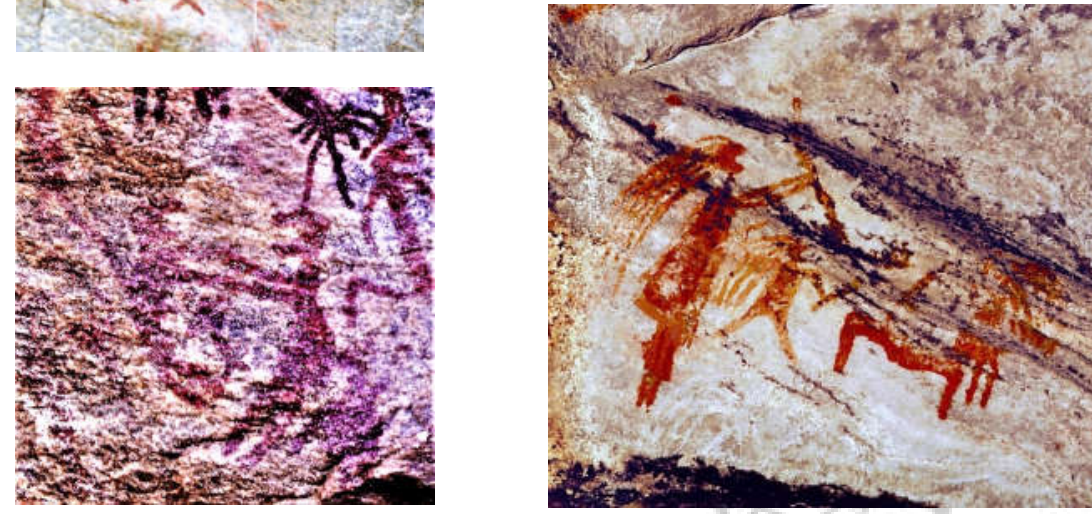

Figura 4a. Cenas com três figuras humanas, uma menor no centro apresentada ou protegida pelas outras dois: A) Xique-Xique II; B) Sítio Mirador; C) Sítio Xique-Xique IV; D) Sítio Casa Santa; F) Sítio XiqueXique II. 

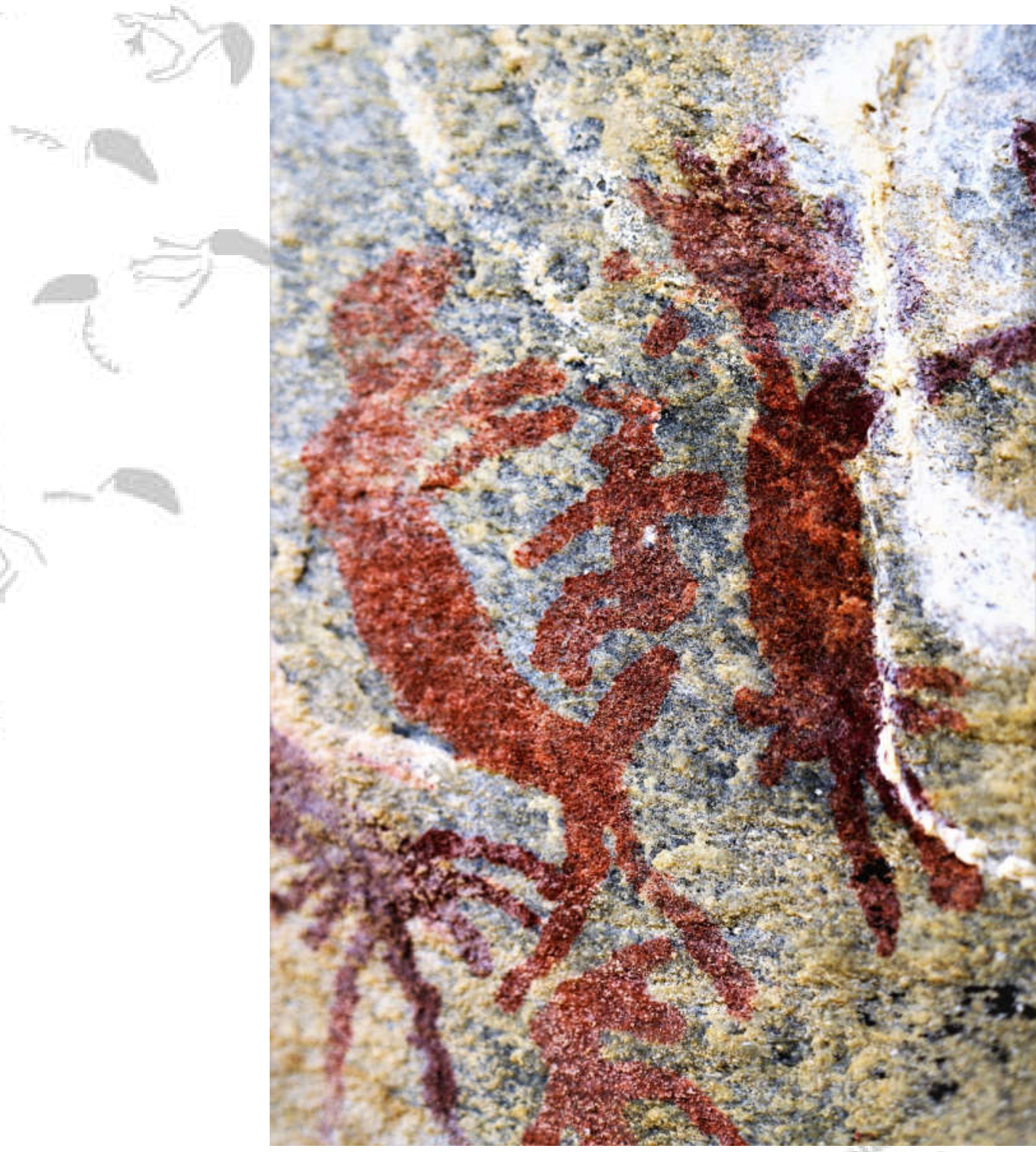

(9)

Figura 4b. Sítio Xique-Xique IV. A mesma cena com três figuras humanas, mas que apresentam marcado dimorfismo sexual.

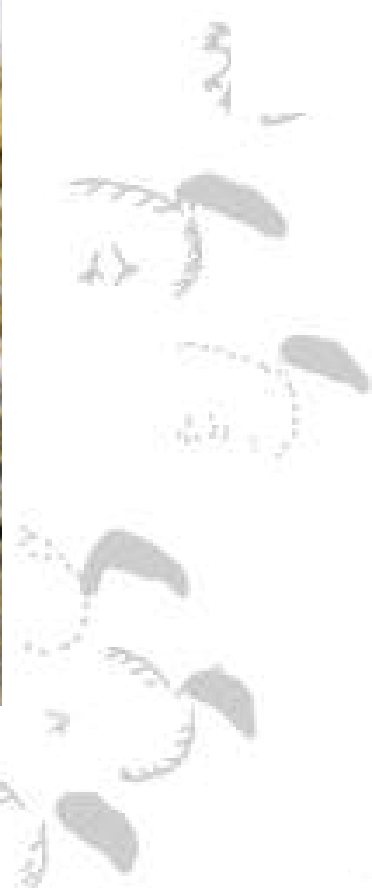


No plano da temática, as diferenças são importantes. Em primeiro termo, salientase o desaparecimento de um tema de fundamental importância nos registros do Parque Nacional Serra da Capivara que são a interação das figuras humanas com espécies animais. As figuras de animais ficam relegadas a um segundo plano no período Recente e apenas as aves ocupam um lugar de destaque em relação com humanos. No período Arcaico é possível identificar um número maior de espécies animais, geralmente isoladas e fora de contexto com pessoas.

Pelo contrário, nas pinturas do período Recente se privilegiam as relações humanas numa ampla variedade de atividades em detrimento das cenas com animais. As representações lúdicas se tornam muito mais complexas que na Serra da Capivara, pois envolvem vários participantes muitas vezes diferenciados pelo instrumento manipulado e pelos atributos e adornos. Essa complexidade se manifesta também nas cenas de luta, nas quais o objeto tem uma importância destacada e na gestualidade se salientam os tempos mais fortes da ação representada. As cenas multiplicam-se na variedade dos grupos de homens e mulheres que carregam bolsas, cestas e potes possivelmente transportando água e alimentos, algumas figuras são singelas na simplicidade de sua aparente nudez, outras, cheias de cocares e atributos, mostram o poder da sua hierarquia. Com armadilhas e jaulas, há caçadores na tocaia e figuras coletando mel com a representação da casa de abelhas e os insetos revoando em torno, (Figura 5). 
Figura 5. Xique-Xique IV, cena de coleta de mel.

Pequenas figuras adornadas com penas ensaiam uma dança de roda, onde os participantes seguram-se pelas mãos e são dirigidos por um mestre de cerimônias ostentando uma máscara. O mundo que aparece nas pinturas rupestres da região do Seridó é o cotidiano da pré-história, (Figuras 6a e 6b). 


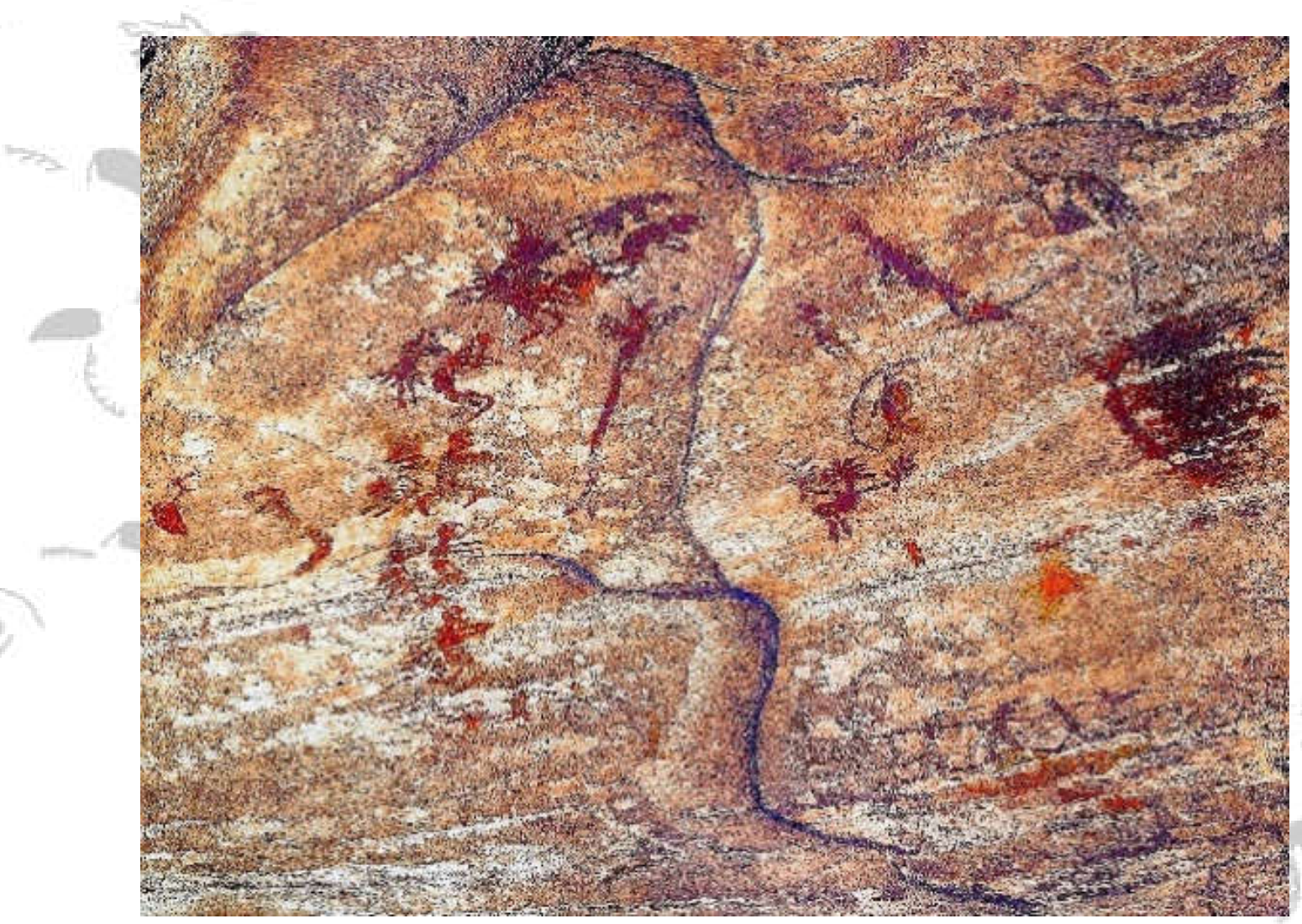

Figura 6a. Painel centrais do Sítio Xique-Xique I.

O tratamento da sexualidade é outro caracterizador das pinturas rupestres do Seridó.

Diferentemente das da Serra da Capivara, em que o sexo feminino está mostrado através de um recurso contra natura, tornando exposta a cavidade vaginal, no Seridó os caracteres sexuais são apresentados no contexto de uma cena sexual. Trata-se de um tema privilegiado no período Recente, com um evidente dimensionamento do aparelho genital, com uma variedade de posturas, de práticas 
e de contextos que evocam mitos estruturados em torno desta temática. Em uma das cenas a figura feminina é segurada por duas figuras de tamanho muito reduzido, que seguram suas pernas no início do ato sexual. Em outra cena de grande violência se representa um falo descomunal em relação às duas figuras humanas.

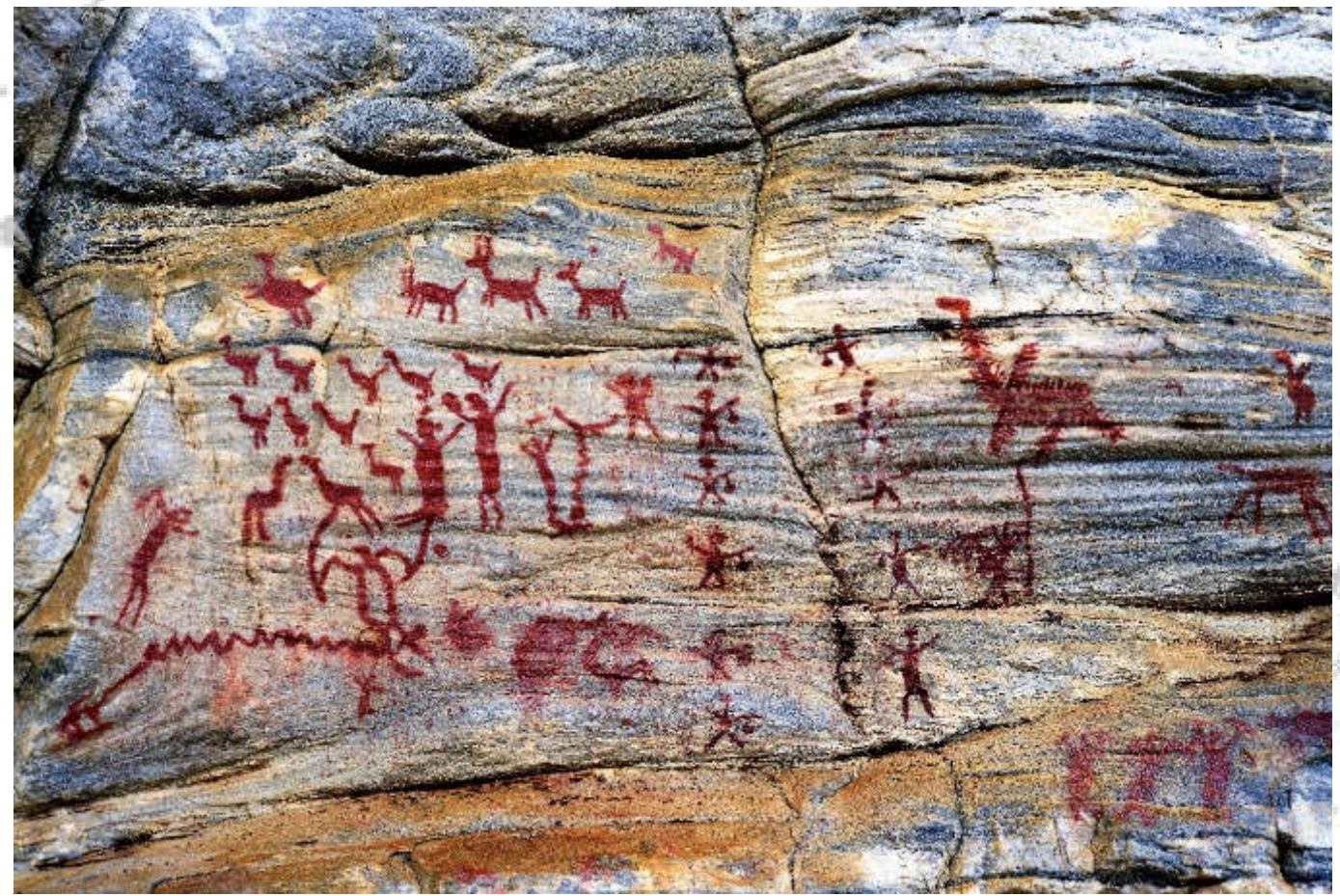

Figura 6b. Painel central do Sítio Xique-Xique II.

Os aspectos cenográficos caracterizam igualmente as particularidades do Seridó. Trata-se dos procedimentos segundo os quais são agenciados os componentes das representações gráficas sendo possível identificar padrões de apresentação que 
variam segundo as transformações culturais das comunidades. Há um domínio da técnica na representação das relações espaciais entre as figuras, na disposição das mesmas na representação da distância e da profundidade, respeitando-se certas regras da perspectiva que permitem identificar a existência de pontos e ângulos de observação muito precisos. O que é apenas esboçado cenograficamente na Serra da Capivara atinge uma expressão muito refinada no Seridó.

Finalizando esta breve exposição sobre os dados básicos da tradição Nordeste, na região do Seridó — a subtradição Seridó — não podemos deixar de chamar a atenção sobre a deriva subjetiva na valoração dos temas das pinturas rupestres na região. Separar o cotidiano do cerimonial nas pinturas eminentemente figurativas é uma forma de reconhecer o que entendemos e o que não, em relação ás mesmas. As cenas que chamamos emblemáticas da tradição Nordeste e que encontramos com maior ou menos profusão, repetidas nas diversas províncias rupestres são, sem dúvida, um nexo de união das ideias dos grupos autores.

Os caminhos materiais da dispersão dessas ideias são ainda hipotéticos, mas partimos do princípio que as ideias avançam mais rápido que os homens e entendemos como ideias o conjunto de mitos, crenças, recursos e técnicas que acompanham o homem na sua diáspora cultural. 

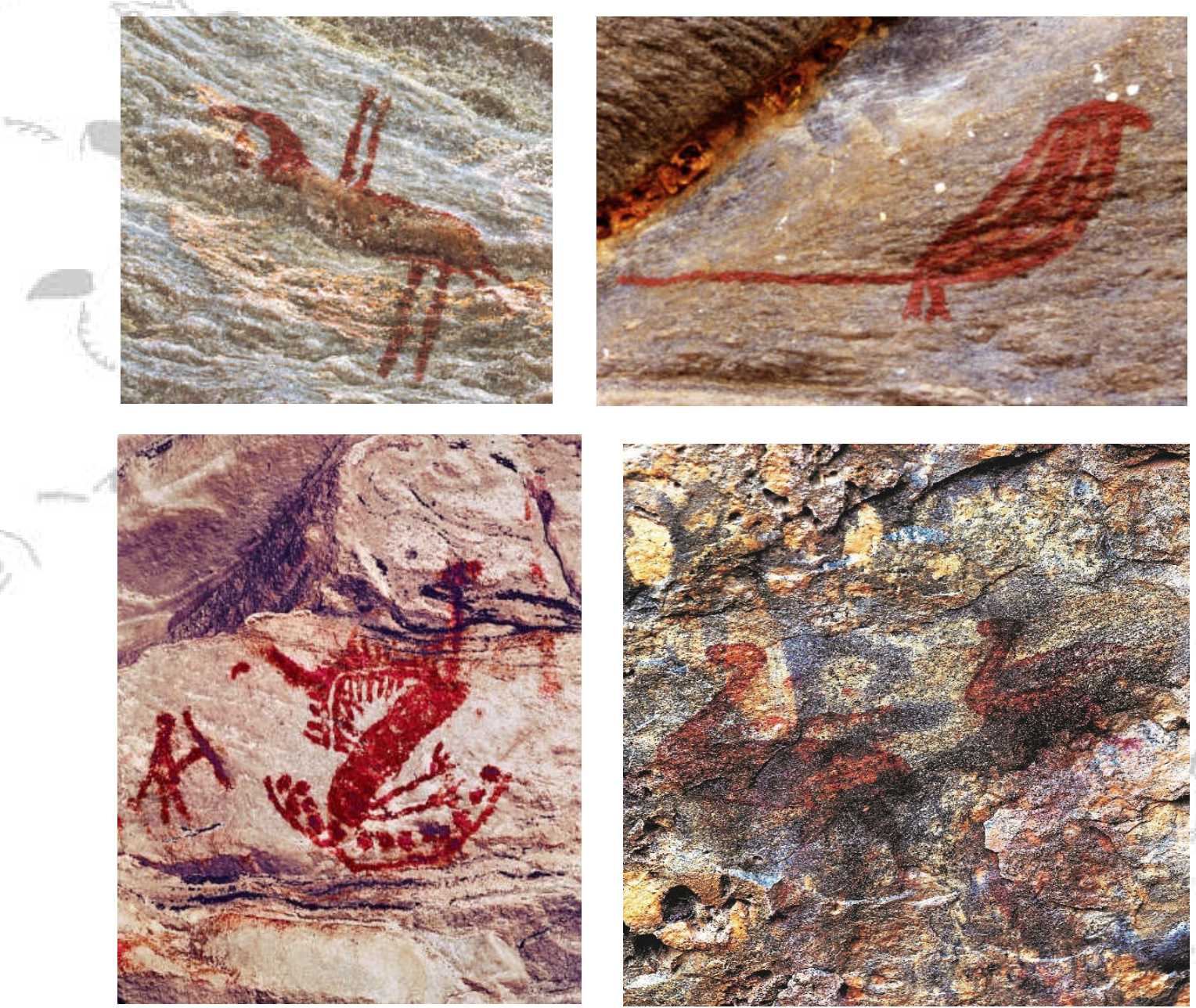

Figura 7. AVES: A) Sítio Mirador; B) Furna do Messias; C) Ave no ninho com ovos, Sítio Xique-Xique II; D) Emas no Sítio Mirador.

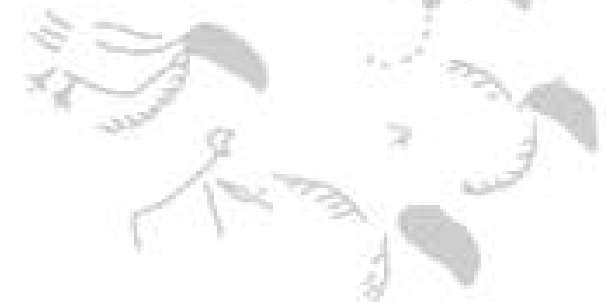




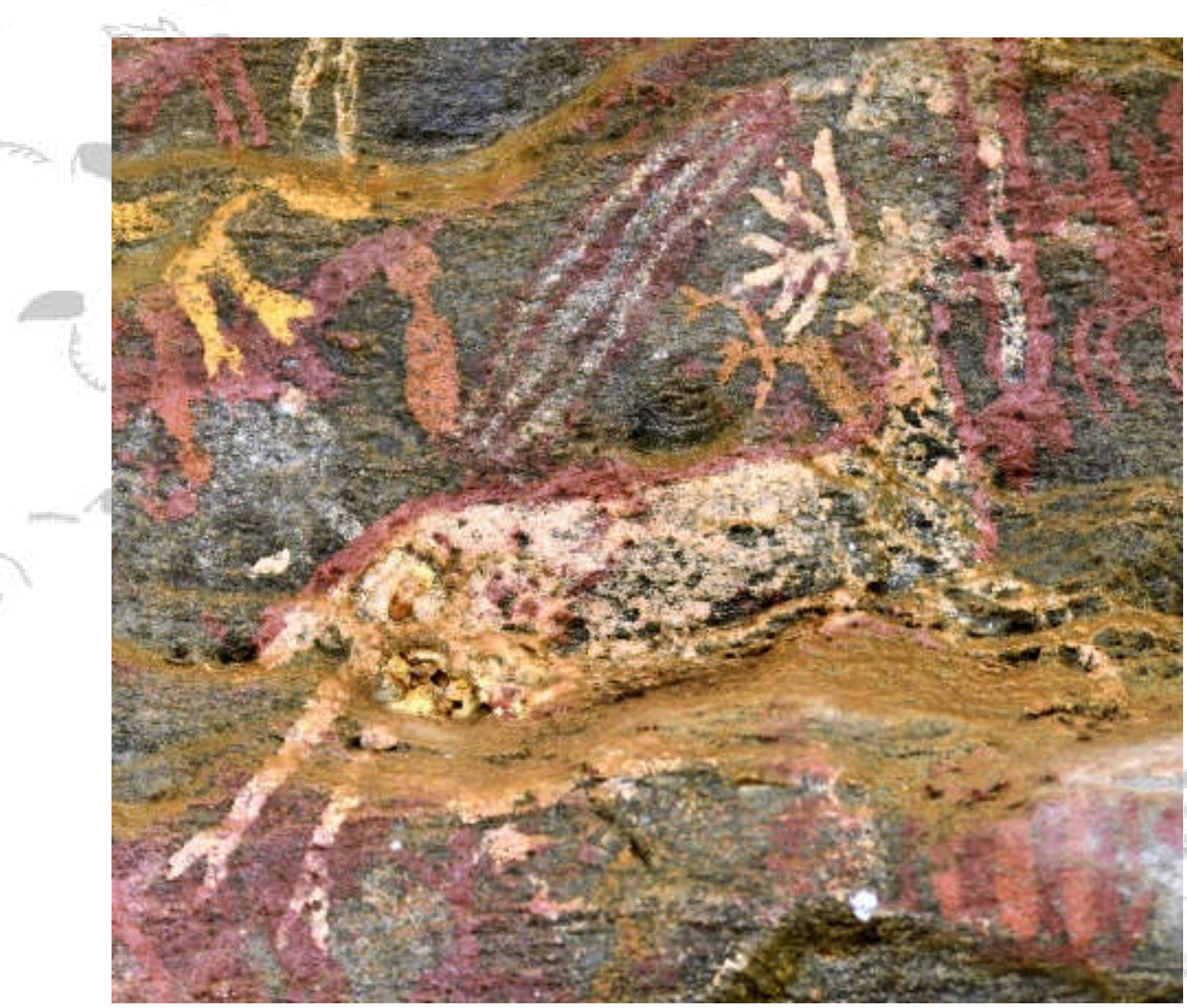

Figura 8. Veado policrômico da Furna dos Caboclos.

\section{As novas técnicas de registro e seus resultados possíveis}

Os que iniciamos pesquisas sobre as pinturas rupestres em décadas passadas, recorremos quase que unanimemente à elaboração de decalques realizados 
principalmente com papel transparente e plásticos. Esses decalques foram depois trabalhados com técnicas as vezes engenhosas para reduzir os painéis copiados e poder estudar os conjuntos no laboratório, ajudados por fotografias. São hoje documentos preciosos que não devem ser desprezados, pois em muitos casos registraram pinturas pré-históricas que hoje não mais existem. Uma exposição no Museo Nacional de Ciencias Naturales, de Madrid, em 2015, apresentou decalques realizados com papel manteiga dos anos de 1920, sobre pinturas rupestres da região leste da Espanha, muitas das quais praticamente já desapareceram.

Na região do Seridó vários fatores têm contribuído para a destruição paulatina dos painéis pintados, pois diferentemente do Parque Nacional Serra da Capivara que é uma área fechada e preservada, o Seridó está dividido em propriedades particulares onde se praticam duas atividades altamente destrutivas: a mineração e o desmatamento para alimentar a indústria de tijolos e telhas muito enraizada na região. Para completar o quadro negativo, a "socialização" praticada pelo IPHAN$\mathrm{RN}$ nos principais sítios com pinturas, instalando passarelas de madeira incitando à visitação descontrolada e sem vigilância alguma, tem sido, também, um elemento de deterioro sistemático do patrimônio rupestre da região.

Com essa advertência queremos chamar a atenção para as novas tecnologias necessárias ao estudo e preservação das pinturas rupestres do Seridó como são a aplicação de técnicas fotogramétricas de alta resolução, na medida que conhecemos o deterioro acelerado que estas estão sofrendo. 
A degradação dos sítios mostra as cicatrizes da rocha provocada pela fragmentação que, com frequência quebraram, também, painéis de pinturas, originando a queda de fragmentos pintados sobre o sedimento arqueológico. Esse lado negativo na conservação das pinturas permitiu, ao menos no começo, se obter datações relativas post quem ao poder datar-se carvão coletado nos sedimentos onde caíram fragmentos desprendidos das pinturas.

Com o tempo e as novas técnicas que a ciência oferece, esses fragmentos permitiram realizar cortes estratigráficos sobre as pinturas e se obter dados precisos em laboratório sobre os corantes e pigmentos utilizados, além das possíveis superposições realizadas. Procedente das escavações em sítios do Parque Nacional Serra da Capivara existe uma quantidade significativa desses fragmentos pintados, em estudo no Laboratório de Registros Rupestres da Fumdham e no de Metrologia da UFPE que se constituí numa coleção de referência para as pesquisas em outras regiões do nordeste, como é o caso do Seridó.

Em razão da complexidade das imagens rupestres estas devem ser consideradas como elementos da base de dados nas pesquisas arqueológicas. Portanto, devem ser submetidas aos mesmos procedimentos de pesquisa aplicados a todos os vestígios arqueológicos. Para que exista a confiabilidade mínima em qualquer interpretação se exige o fundamento fatual e o benefício da prova. 
Datar as pinturas rupestres de maneira precisa e confiável não é ainda uma tarefa possível. Isto, apesar dos numerosos resultados fornecidos pela diversidade de técnicas utilizadas em amostras de sítios arqueológicos. Múltiplas datações e técnicas de amostragem tem demostrado a importância de adaptar esses processos às condições específicas de cada sítio. Datar pinturas rupestres utilizando um método construído pela combinação de vários procedimentos arqueométricos é uma abordagem complementar às técnicas clássicas de datação por radiocarbono. A pesquisa sobre técnicas arqueométricas combinadas tem sido privilegiada pelos pesquisadores que trabalham na região nordeste do Brasil.

As pinturas rupestres são vestígios gráficos de sistemas de comunicação de grupos de tradição oral. Uma das disciplinas principais que aporta elementos à reconstrução da pré-história é a sedimentologia, que trabalha diacronicamente para estabelecer elementos sincrônicos numa unidade de tempo. Outra disciplina, a paleontológia procura posicionar cronologicamente a evolução das espécies de fauna e flora que caracterizam os diferentes solos pré-históricos.

São as escavações arqueológicas horizontais amplas que fornecem dados sobre a diversidade dos solos. A construção do contexto cultural de cada nível sedimentário se atinge através da identificação das etapas da cultura material. Mas são as análises técnicas afinadas dos vestígios materiais que permitem reconstruir o acervo técnico de grupos humanos e a evolução da inovação para melhor adequação às suas necessidades. 
A descoberta de sítios arqueológicos com pinturas rupestres tem-se incrementado, de maneira considerável nas últimas décadas. $\mathrm{O}$ incremento do acervo de imagens rupestres viabiliza pesquisar um universo imagético maior, a um nível mais particular e preciso do que o realizado até os primeiros resultados. Trata-se de aprofundar as análises das classes estilísticas derivadas, que permitem extrair conclusões de caráter geral e propor explicações também gerais. O acervo gráfico maior disponível na atualidade, viabiliza tornar as conclusões gerais em hipóteses a serem estudadas em níveis analíticos precisos.

Fica evidenciado que, além do estudo de variáveis estilísticas, que caracterizam a ampla tradição Nordeste, ao longo do tempo e do espaço regional, se faz imprescindível o aporte de novos conhecimentos obtidos com procedimentos científicos confiáveis. Esses procedimentos abrem espaços que levam a articular combinações integrando a física, química, geoarqueologia, bioarqueologia e metrologia arqueológica e patrimonial.

O levantamento dos vestígios de pinturas rupestres existentes nos sítios arqueológicos é o primeiro procedimento que foi aperfeiçoado com novos registros documentais. Para reproduzir e conservar as imagens rupestres sobre suportes que as defendam da deterioração, é preciso proceder com a maior precisão à maneira de como se aplicam nos vestígios evidenciados nas escavações. Como numa escavação os dados não são acessíveis de maneira direta, devem ser extraídos exaustivamente. A história do registro dos acervos rupestres é a trajetória da procura de recursos 
técnicos para se obter uma documentação completa e inalterada do estado de conservação do sítio como um todo, no momento em que é realizado. Quando, na preparação da documentação intervém a mão humana, esse produto copiado tem distorções que podem decorrer de várias causas. Algumas delas são a técnica utilizada, a natureza do suporte da cópia e as escolhas do pesquisador, que, por sua vez, dependem de sua percepção seletiva. São documentos imagéticos que ficam distanciados do original pela alteração introduzida pelo pesquisador e suas exclusões involuntárias. A cada ano, são numerosos os sítios com grafismos rupestres pré-históricos destruídos irrecuperáveis. Face a este aumento de destruição patrimonial tornou-se um objetivo principal adotar novas técnicas de reprodução e armazenamento digital do acervo imagético dos sítios da região Nordeste. O registro integral do acervo rupestre, através da técnica de varredura a laser é o recurso mais exato que existe atualmente.

O processamento dos dados imagéticos que permite uma reconstituição digital georreferenciada e fotográfica de alta resolução, exige um afinado trabalho de adequação à situação especifica de cada um dos sítios escolhidos. Assim, é documentado por procedimentos de varredura a laser, o registro georreferenciado dos sítios arqueológicos e das manchas gráficas realizadas sobre as paredes dos sítios escolhidos, obtendo-se a reconstrução do espaço-objeto a partir do espaço da imagem. O objetivo da aplicação do método é construir uma documentação que ficará armazenada em discos rígidos. A imagem digital deverá conservar os mínimos detalhes da imagem real, utilizando o tamanho de pixel reduzido. 
Concretamente, nas pinturas da subtradição Seridó, se iniciou o registro sistemático georeferenciado a partir do grande painel do Sítio Casa Santa e da sequência de sítios da série Xique-Xique, em Carnaúba dos Dantas.

As pesquisas metrológicas e sua aplicação arqueométrica incrementaram-se com a possibilidade de utilizar instrumentos portáteis e técnicas para a análise do pigmento das pinturas rupestres. Os dados provenientes da utilização da microscopia digital, fluorescência de Raios-X, difratometria de Raios-X (DRX) e espectrofotometria e espectroscopia de emissão em plasma induzido por laser, LIBS, para o estudo das pinturas rupestres, fornecem informações sobre os elementos componentes das pinturas e das técnicas utilizadas na sua confecção, a fim de que se possa distinguir pigmentos com elementos semelhantes e também diferentes.

A espectroscopia de emissão em plasma induzida por laser, LIBS, é uma técnica de análise que permite a decomposição dos elementos de uma amostra mineral. $\mathrm{O}$ procedimento utilizado é quase não-destrutivo, pois apenas altera o ponto da amostra atingido pelo laser. Fornece uma análise elementar de todo o espectro de elementos com uma resolução espacial quase microscópica. Existem instrumentos para a obtenção de espectros que são portáteis e que por seu formato são uteis para amostras que não podem ser deslocadas. 
Uma serie de interrogantes decorre de problemas que aparecem no curso da pesquisa dos vestígios gráficos rupestres. Para sua solução, a participação dos laboratórios de metrologia se torna essencial. Alguns dos assuntos a serem considerados são: Estabelecer os fatos arqueológicos em sequencias cronológicas confiáveis é um dos problemas que dependem dos métodos aplicados. Quando não podem ser obtidas datações absolutas pela natureza da amostra disponível, existe o recurso de datações relativas. Estes métodos permitem situar numa escala de tempo relativa, fatos relacionados que permitem deduzir uma continuidade a partir dos tipos de relações que esse fato mantém entre eles. $O$ termo relativo não se refere à imprecisão, mas aos fatos inter-relacionados, configurando uma cronologia confiável.

Determinar possibilidade de relação entre as tintas utilizadas para pintar os ossos em enterramentos secundários e as pinturas rupestres realizadas sobre a parede do abrigo sob rocha utilizado como cemitério pode aportar informações cronológicas. Existem evidencias de que certas pinturas foram repintadas várias vezes com tintas diferentes tanto na textura quanto na cor. É necessário poder reconstituir o processo de deposições sucessivas da tinta sobre a parede tendo em conta o processo de degradação por ação de agentes naturais e antrópicos, para identificar a estratigrafia pictural. Precisa-se identificar as alterações de amostras por impactos tafonômicos.

Foi realizado um teste experimental com dois fragmentos de pinturas rupestres pertencentes a dois sítios arqueológicos brasileiros, um do Sítio Toca da Extrema 
II do Parque Nacional Serra da Capivara e outro do Sítio Xique-Xique I, do Seridó, (Borba, F. de S.L. et alli, 2012) Foram analisados por LIBS (espectroscopia de emissão em plasma induzido por laser), com instrumento construído no laboratório (laserNd:YAG, 1064nm,5,2ns) contendo um policromador échelle, empregado para a aquisição dos espectros. Para cada fragmento de pintura realizaram-se 8 pulsos sucessivos em 16 locais diferentes, sendo 8 sobre a pintura e 8 sobre o substrato. Nesse trabalho, foi demonstrado que a utilização de técnicas multivariadas é indispensável devido à grande complexidade dos espectros obtidos durante o estudo da profundidade de amostras arqueológicas.

A análise da amostra do Sítio Xique-Xique mostra que a primeira camada encontrada em toda a superfície da amostra apresenta composição semelhante ao substrato. Isso pode ser devido a processos causados eólicos que depositaram uma camada de impurezas na parede do abrigo, com composição semelhante às rochas circundantes. Em relação à constatação de uma primeira camada de impurezas na área da pintura, existe a possibilidade de duas abordagens visando o estudo da amostra: se o objetivo é determinar a idade de aplicação da tinta na parede rochosa, a primeira camada deve ser removida, mas se o objetivo é estudar a evolução do processo de deposição de agentes exógenos naturais, a transformação do substrato rochoso, que contém as pinturas ou a deposição de componentes químicos, a determinação da composição da primeira camada torna-se essencial. LIBS é uma técnica útil para analise arqueológica em razão de não requerer preparação da 
amostra. Fornece rapidamente análises multi-elementares mesmo para elementos leves e quando a resolução espacial é quase microscópica.

No caso do Laboratório de Perfil Técnico, Lapet, do Núcleo de Metrologia Arqueológica da UFPE, e que é operacional desde 2019, são realizadas as técnicas analíticas de fluorescência por Raio - X, da qual se obtém os elementos químicos, a preparação de amostras para Difração por Raio - X, na qual se identificam os minerais, e a produção de lâminas petrográficas, nas quais podem ser identificados visualmente os minerais.

Cabe salientar que as lâminas, embora impliquem em um processo destrutivo, permitem extrais dos fragmentos questões fundamentais que servem de referência para trabalhos de campo não destrutivos. É o caso de questões antrópicas como a textura, as camadas e a interação entre os pigmentos e o suporte. De forma semelhante ocorre com os dados obtidos através da difração por Raio - X, pois os minerais indexados em laboratório e a partir das amostras permitem estabelecer um banco de dados de referência que contribuem para identificar in situ os minerais com um microscópio portátil de baixo custo. Com essas análises pretende-se estabelecer padrões técnicos de aplicação aos pigmentos e tentar associá-los às subtradições é um dos objetivos das pesquisas em andamento no Lapet, (Figura 9). 
Figura 9. Laboratório de Perfil Técnico, Lapet, do Núcleo de Metrologia Arqueológica, da UFPE.

\section{BIBLIOGRAFIA DE REFERÊNCIA}

Nota das autoras:

A bibliografia arqueológica sobre a região do Seridó é muito extensa e, em parte, está registrada nos artigos de este número de Clio dedicado à região. Neste artigo fazemos referência apenas aos trabalhos pioneiros e aos que refletem as primeiras hipóteses válidas em relação às origens e dispersão da Tradição Nordeste entre o SE do Piauí e o vale do Seridó. 
BORBA, Flávia de S.L.; CORTEZ, Juliana; ASFORA, Viviane, K.; PASQUINI, Celio; PIMENTEL, Maria Fernanda; PESSIS, Anne-Marie; KHOURY, Helen J. Multivariate Treatment of LIBS Data of Prehistoric Paintings. J. Braz. Chem. Soc.; VOL 00. No. 00. 18. 2012. Sociedade Brasileira de Química.

GUIDON, Niède; ANDREATTA. O sítio arqueológico Toca do Sítio do Meio (PI). Clio Revista do Curso de Mestrado em História n.3, UFPE, 1980, p.7-70.

GUIDON, Niède. Peintures rupestres de Varzea Grande, Piauí, Brésil. Cahiers d'Archeologie d'Amerique du Sul, n.3, EHESS, 1975, Paris.

Datações pelo C14 de sítios arqueológicos em São Raimundo Nonato, sudeste do Piauí (Brasil). Clio Revista do Curso de Metrado em História n.4, UFPE, 1981, p. 35-38.

. Da aplicabilidade das classificações preliminares na arte rupestre. Clio Revista do Curso de Mestrado em História, n.5, UFPE, Gráfica Caxangá, Recife, UFPE, 1982, p. 117- 128 .

A arte pré-histórica da área arqueológica de São Raimundo Nonato (PI): síntese de dez anos de pesquisas. CLIO - Serie Arqueológica, n.2, Ed. UFPE, Recife, 1985, p. 380 .

LAGE, Maria da Conceição Meneses; FABRIS, José Domingos; MORAES. Beneilde Cabral; CAVALCANTE, Luis Carlos Duarte. Análise química de sedimentos como indicador de ocupação humana pré-histórica no Parque Nacional Serra da Capivara. CLIO - Serie Arqueológica, vol.1 n.20. Recife, Ed.UFPE, 2006, p.103-122.

MARTIN, Gabriela. Estudios para una desmitificación de los petroglifos brasileños. Papeles del Laboratorio de Arqueología de Valencia. n. 11, Universidad de Valencia, (España), 1975. p. 203-237.

. Casa Santa: um abrigo com pinturas rupestres do estilo Seridó, no Rio Grande do Norte. CLIO - Revista do Curso de Mestrado em História. n. 5. Recife: UFPE, 1982. p. $55-78$.

Amor, violência e solidariedade no testemunho da arte rupestre brasileira. CLIO Série Arqueológica. n. 1. Recife, UFPE, 1984. p. 27-37. 


\section{Clio Arqueológica 2020, V35N3, p.18-59, PESSIS; MARTIN DOI: 10.20891/clio. V35N3p18-59}

O Estilo Seridó na arte rupestre do Rio Grande do Norte. Arquivos do Museu de História Natural. v. 6-7, (1981-1982). [Atas da I Reunião Científica da Sociedade de Arqueologia Brasileira] Belo Horizonte: UFMG; Museu de História Natural, 1984. p. 379382.

Arte rupestre no Seridó (RN): O sítio "Mirador" no Boqueirão de Parelhas. CLIO - Serie Arqueológica n. 2. Recife: UFPE, 1985. p.81-96.

Fronteiras estilísticas e culturais na Arte Rupestre do Seridó RN. CLIO Arqueológica n. 16, Recife: UFPE, 2003. p. 14-28.

Identidades no Sertão do Seridó ( p. 164-175) In: ANTES: HISTÓRIAS DA PRÉHISTÓRIA. São Paulo 2004, Centro Cultural Banco do Brasil. São Paulo.

MARTIN, Gabriela; PESSIS, Anne-Marie. Da Serra da Capivara-PI ao Seridó-RN. Os caminhos da Tradição Nordeste da Arte Rupestre do Brasil. FUMDHAMentos - Revista da Fundação do Homem Americano. n. II. São Raimundo Nonato: FUMDHAM, 2002. p. 252-269.

MARTIN, Gabriela; MEDEIROS, Elisabeth. A Furna do Messias: um sítio com pinturas rupestres na área arqueológica do Seridó, no Rio Grande do Norte. Clio Arqueológica. 2. n. 23. Recife: UFPE, 2008. p. 70-86. (CD).

PESSIS, Anne-Marie. Méthode d'analyse des représentations rupestres. Études Américanistes Interdisciplinaires. Contributions Méthodologiques en Préhistoire I. n. 1. Paris: [s. n.], 1982a. p. 17-28.

. Métodos de documentação cinematográfica em arqueologia. Clio Revista do Curso de Mestrado em História da UFPE, n. 5, Gráfica Caxangá, Recife, UFPE, 1982, pag. 129-138.

. Métodos de interpretação da arte rupestre: análises preliminares por níveis. Clio Arqueológica, n.1, Recife, UFPE, 1984 p. 99-108.

A dispersão da Tradição Nordeste: da Serra da Capivara (PI) ao vale do Seridó, $\overline{(\mathrm{RN}-\mathrm{PB})}$ Projeto 2003:

http:// www2.ibama.gov.br/unidades/apas/docleg/109/dnn040897.htm 
Imagens da Pré-História. Parque Nacional Serra da Capivara. Images de la Préhistoire. Images from pre-history, São Paulo, 2003, FUMDHAM, Petrobrás, Ministério da Cultura. Gráfica Takano. 307 p. São Paulo. 2aEd., São Paulo, 2013, MCTI/CNPq, 320 p.

Inovação técnica e sobrevivência: A natureza como exemplo. (p.244-32). A transmissão do saber na arte rupestre do Brasil (p.142-163) In: ANTES: HISTÓRIAS DA PRÉ- HISTÓRIA. São Paulo 2004, Centro Cultural Banco do Brasil. São Paulo.

PESSIS, A-M.; GUIDON. n. Registros rupestres e caracterização das etnias pré-históricas. In: Vidal, L. (org.). Grafismo Indígena. Estudos de Antropologia Estética. São Paulo: Studio Nobel, FAPESP; EDUSP, 1992. p. 19-34.

PESSIS, Anne-Marie; MARTIN, Gabriela. A Arte pré-histórica do Brasil: da técnica ao objeto. In: Fabiana Werneck Barcinski, (org.). Sobre a Arte Brasileira - da Pré-história aos anos 1960. São Paulo, Ed. Edições SESC/WMF Martins Fontes ,2015. p. 22-61.

PESSIS, Anne-Marie; COSTA, Adriene; CISNEIROS, Daniela; CASTRO, Viviane. Prospecção arqueológica de sítios com registros rupestres na Chapada do Araripe. Clio Arqueológica, Recife, UFPE, 2005, p. 123-140.

PESSIS, Anne-Marie; MARTIN, Gabriela; GUIDON, Niède. Da confiabilidade das classificações arqueológicas dos registros gráficos rupestres da Pré-história. In: Os biomas e as sociedades humanas na pré-história da região do Parque Nacional Serra da Capivara, Brasil, 2014, Vol.IIB. p.643-660.

PESSIS, Anne-Marie; CISNEIROS, Daniela; MUTZENBERG, Demétrio; MEDEIROS, Elisabeth. Modelos tridimensionais na análise de pinturas rupestres. In: In: Os biomas e as sociedades humanas na pré-história da região do Parque Nacional Serra da Capivara, Brasil, 2014, Vol.IIB. p.663-704. 